$\xi=-1$

\title{
Organization of Financial Reporting in Accordance with Requirements of the IFRS Taxonomy
}

\author{
N. V. Chebanova ${ }^{1}$, T. I. Yefimenko ${ }^{1}$, V.M. Orlova ${ }^{1}$, N. N. Korolova ${ }^{2}$ \\ ${ }^{1}$ Ukrainian State University of Railway Transport, Kharkiv, Ukraine \\ ${ }^{2}$ Academy of Labour, Social Relations and Tourism Sociology and social sciences departmen \\ *Corresponding authors E-mail:t.efimenko22@gmail.com
}

\begin{abstract}
The authors of the article exposed the methodical questions of introduction, new for the registration process of Ukraine of the phenomenon. It is taxonomy of the financial reporting (TFR). At the same time continued consideration of questions of the use of the financial reporting for the acceptance of administrative decisions.

Essence of TFR is exposed in the context of classification and systematization of ingredients of the financial reporting. It in itself informative system and connections between the constituents of such system. Authors suggested to attribute TFR to the mathema tical determined models. The construction of such models requires the clear plan of actions in three steps: a mathematical model - an algorithm of calculation - computer program. The purpose of researches: of one times to prove that introducing in economic science of exact knowledge, enables to limit the intuitional acceptance of administrative decisions and extend the limits of application of rational methods. It will be realized on condition of the use of different methods, methods and approaches - from nonlinear, stochastic models to the modern programming languages .
\end{abstract}

Keywords: administrative decision; financial reporting; informative model of enterprise; record-keeping; taxonomy.

\section{Introduction}

Fulfilling by Ukraine its obligations under the Association Agreement with the EU provides for the harmonization of legislation, including accounting and audit, with the legislation of the European Union. The coordination measures have been established by Directive 2013/34/EU of the European Parliament and of the Council of 26 June 2013 No. 2013/34/EU on the annual financial statements, consolidated financial statements and related reports of certain types of undertakings [1]. In accordance with this, the Law of Ukraine "On Amendments to the Law of Ukraine "On Accounting and Financial Reporting in Ukraine" regarding the improvement of some provisions $[2,3]$ introduced amendments to the Law of Ukraine "On Accounting and Financial Reporting". The law introduces to the concept of "financial reporting taxonomy". The study of the content and essence of the financial reporting taxonomy (hereinafter FRT) refers to the information and accounting issues for making of managerial decisions $[4 ; 5]$.

Relevance of the study of the reporting taxonomy as a prototype of the information model of the enterprise is confirmed by V.M. Zhuk, who speaks about the importance of the managers' ability to work with financial reporting, about "the role of information in the management system of the economy (business), which provides the priority of financial reporting in the system of providing information for the management;" about "changing the attitude to information in the market conditions, when it becomes a specific product with all consequences (such as commercial secret, value, price, etc.)" [6]. It should be envisaged that FRT as an "open information system" [7] has inherent properties that determine the ability of the system to respond to changes in the environment.

\section{Taxonomy, as an Informative Model}

Analysis of recent studies and publications on issues of analysis of changes in the requirements for the reporting composition and content for European companies as a result of the introduction of a new EU accounting directive shows the absence of explicit wording on the essence of the financial reporting taxonomy in the scientific literature. To clarify this, we have to use some peripheral information.

Taxonomy is a term of Greek origin defined as "the theory of classification and systematization of complex phenomena, concepts and objects" [8]. That is, for financial reporting this is the principle of systematization of statement items and other information about the financial position, financial results, total revenue, and cash flow of the company. The content of the financial statements consists of the items and the taxonomy which actually links these articles.

Supporters of the systemic approach in decision making see the opportunity to "simulate the situation in time" for implementation of the idea of "single information space of the enterprise" as one of the prerequisites to supporting the concept of the financial reporting taxonomy [9].

Characterizing the financial reporting taxonomy from the standpoint of systemic theory, we would like to note such mandatory properties as "divisibility, integrity, hierarchy, integratedness and communicativeness" [7,9]. The property of the taxonomy (the system is not isolated, it interacts with the environment, while the environment and the system affect each 
other), which provides its unity with the environment, which at the same time sets certain requirements and restrictions for it, is of special interest for implementation of the accounting of information modeling of the enterprise.

If the financial reporting taxonomy is considered as an "open information system" [7], it has the features that determine the ability of the system to respond to changes in the external environment.

Determining the purpose and objectives of the study. Determining the content of the financial reporting taxonomy as a system in which accounting can be implemented for the benefit of the efficient business management deserves to be the objective of the study.

The purpose of the article was clarification of the essence of the financial reporting taxonomy, fulfillment of the enterprise management tasks, as well as the theoretical substantiation of compliance of FRT with the information model of the accounting system of the enterprise.

The main part of the study. Taxonomy as information modeling of an enterprise involves the creation of a "digital prototype", which is based on the static digital information (such as technical rationale, standards, norms) and should be constantly updated with the changing information (statistical and other reporting, business analysis, data on the state of economic processes, market assessments, etc.). Such information can be provided primarily by accounting, which has historically been formed as a system of "integral and continuous observation and registration of facts of economic life" [3].

"Taxonomy" is just a name of systematization. Therefore, there is no taxonomy as such - only a record of its existence [10]. And the things that are real in taxonomy are its elements. For example, the taxonomy of the "Financial Statement" is just a name, while the sections created in the statement are real - such elements as revenue, expenditures, interim financial results, etc. For example, if not a single section is created, then it conventionally can be said that there is no taxonomy (it is empty) - it is not recorded anywhere in the database, but exists only in variable items, where the taxonomy name and its properties (options) are specified. The records are associated with the taxonomy elements, but not to the taxonomy itself. Since the records are associated not with taxonomy, but with its elements, then all subsequent working with taxonomy is working with its elements.

Introduction of the financial reporting taxonomy through the information modeling of the enterprise involves selecting from the set of elements of a real object such its properties and connections which are essential for the purposes of modeling. Such selection is carried out as the sequence of transition from the real object to the information model: 1) characteristics of the real object; 2) analysis of origin; 3) system of the data essential for modeling; 4) information model. This sequence to the main groups of accounting objects (such as assets, capital, liabilities, income, expenditures, and cash flows) can be used with the modern methodology of compiling financial statements in accordance with the Accounting Standards (in Ukraine). For example, for representing the assets taxonomy, this may appear like this:

1) taxonomy of the characteristics of a real object. Assets are the property of an enterprise, which is a set of items purchased through investment and receiving loans, and therefore represent the essence of the company's relations with external economic agents (the value of the assets in the active market, debt, etc.);

2) taxonomy of the ways of origin. The enterprise acquire assets and liabilities "as a result of past events", and they are recognized in the financial statements provided there is reasonable "expectation of receiving economic benefits in the future and the availability of reliable estimates";

3) taxonomy of expenditures. The following data are relevant for modeling: the initial value at the moment of receipt, following expenditures in the process of use, presence of signs of devaluation, the liquidation value, etc.;

4) the taxonomy will also include valuation of assets, assets structure, useful lives, performance indicators, indicators of the growth of assets value or their depreciation. An example of an asset index that is not covered by the taxonomy is the prime cost. "The prime cost of products, works and services" is a definition of a certain class of concepts that are metalinguistic formations. The category of "production prime cost" is used in the tasks of systematization of economic knowledge in the cognitive or analytical process. The category "production cost" is used in the tasks of systematization of economic knowledge in the cognitive or analytical process. This category is a constituent element for categorical schemes in many economic subjects, and due to its "decryption possibilities" [11] is the carrier of procedural moments of taxonomy itself. The Accounting Standards [12] contain no specific definition of the production prime cost, but only describe it in Paragraph 11 by listing the "expenditures" which it includes.

\subsection{Providing of Quality of Taxonomy, by Means of Observance of Principles of Preparation of the Financial Reporting}

The traditional accounting system is based on the regulatory norms that regulate the legal and methodological basis of accounting, namely: the composition and content of information for reporting users, addressees and time of filing. State regulation prevents enterprises from responding to emergence of new accounting objects faster than a "governmental methodologist" of the Ministry of Finance, which restricts the taxonomy. We would like to note that the Accounting Standards as tools for providing information about the financial standing and performance of economic agents are quite flexible. Practically every standard provides for alternative methods of evaluation objects, but the rigid reporting format [13] and the prevalence of tax interests in the "recognition" and "evaluation" of objects in accounting limit the information modeling of taxonomy.

Principles of preparation of financial statements stated in the Accounting Standards, Section 1 "General Requirements for Financial Reporting" can be categorized depending on their importance for ensuring the taxonomy quality, as follows:

- principles used as assumptions for the unambiguous interpretation of the space and time parameters in the taxonomy, as well as for excluding any influence of subjective factors on the reliability of accounting;

- principles used for recognition, measuring and reflecting in the taxonomy of items and economic processes, i.e., to respond to economic phenomena. These principles include the principle of full disclosure, the principle of a single monetary measure;

- taxonomy principles functioning as the "rules of choice" of the alternatives of recognition and evaluation, which ensure the usefulness of financial reporting information, in particular, the susceptibility of accounting methods to emergence of new characteristics in the objects of accounting. These principles include prevalence (predominance) of the essence over the form, profitability (benefits must cover the costs), prudence, consistency. For example, the principle of periodicity allows dividing the time of the enterprise into the time "before the change" and time "when new circumstances and objects be should taken into account" in the accounting and reporting.

The circumstances of implementation of the International Financial Reporting Standards (IFRS) in Ukraine are also related to FRT. The configuration of the modern Ukrainian institutional environment does not contribute to the recognition of IFRS by a 
wide range of practicing accountants as a methodology that meets the information needs of Ukrainian managers and business owners. Ukrainian users still do not understand the information value of the IFRS since at the present time there is no explicit set of indices which is just provided for by FRT.

Confrontation between IFRS and US GAAP (Generally Accepted Accounting Principles of the United States) also has the "taxonomic" roots. Although the US declares the adaptation of US GAAP to IFRS, it keeps initiating reformation of IFRS in accordance with the US GAAP standards. Excluding the principle of prudence from the Conceptual Framework for Financial Reporting proves the current prevalence of the GAAP in the United States. This can be explained as refusal to assess the assets and liabilities by the credit market priorities (banks are the main source of funding in Europe, and they assesses the property at the lowest cost) and the commitment to evaluation by the stock market quotes (stock market remains the main funding environment for the US), where the minimum score is not always recognized as "reliable" [13; 14].

\subsection{Including to Taxonomy of Requirements, in Relation to Authentication of Risks of Record- Keeping}

The necessity to bring enterprises to conformity at the expense of inclusion of the provisions as to the identification of bookkeeping accounting risks has been proved.

Essence of book - keeping risks is exposed. Chosen context of threat of loss to authenticity of account and decline of quality of the financial reporting. Offered approach to authentication of book - keeping risks. The values of ingredients of method of record - keeping are certain. This setting consists of decline of risks of unauthenticity of account. Analytical research of sources of risks is executed in the article. Risks of follow from registration assumptions. The structured description of risks is offered educed at consideration of nature of "tax differences". Tax differences, it is factors warnings threats of distortion of profits and charges of payers of taxes.

The performance of accounting assessments is connected with a number of assumptions. These assumptions concern: the term of an asset useful service, its fair value, utilization value etc. Assumptions are the product of a professional judgment. Any judgment is subjective. The subjectivity of assessments creates the risk of losing the accuracy of accounting and financial statements.

The article proposes to enlarge the contents of the decree on accounting policy. It is reasonable to include in the decree the demands concerning the revelation of the cases of variation choice of assessments in the financial statements. It has been declared that accounting risk can appear in the cases when laws and regulations provide more than one variant of assessment. Accounting risks regarding assets and obligations reveal themselves in initial assessments. The initial assessments are used by the enterprise for distribution of expenditures and profits between corresponding reporting periods. Such distribution is partially based on professional judgment and consequently creates the thread of the decrease of the financial statement quality and the risk of financial result deformation. Methods of realization of work.

The aim of above mentioned threats minimization is reached at the expense of techniques of risk factors influence prevention. The issues of infoware of making managerial decisions have been investigated in the article. The method of accounting policy formation has been improved. The uncertainty in bookkeeping accounting has been researched. This allows discovering circumstances and factors of bookkeeping accounting. Results of researches. The influence of accounting risks subsequences on the accuracy of accounting and objectivity of accounting estimates has been proved [15].

\subsection{Actuality of Input of Taxonomy}

Relevance of the introduction of taxonomy as information modeling of the enterprise is shown in the following:

- $\quad$ accounting and financial statements of the enterprise are used for forecasting. Otherwise, it would not make sense to spend efforts, time and money for its preparation. The changed format of the financial statements may change the view on the structure of the company's assets and liabilities, as well as influence the decision making, i.e., cause "economic consequences";

- the general social and economic situation in the country influences the methodology for evaluation of accounting and reporting, including by taking into account risks;

- $\quad$ sources of funding become crucial for choosing concepts for recognition of objects and their evaluation. If the company is financed through the stock exchange, that is publicly, the quality of the published reporting is expected to be higher than when financing comes from private transactions or loans (the persons who provide financing and receive the necessary information under a private agreement, are at risk to be victim of fraud).

Accounting, as any system, has external and internal connections, both direct and inverse. For such type of connections it is assumed that the presence of some elements of the system determine the need for other elements that interact with the first ones. Thus, assets, liabilities and equity determine the existence of revenues and expenses that result in changes in equity. Such connections allow constructing the FRT structure.

The study of such an economic object as an enterprise through the FRT can be considered as economic and mathematical modeling of this object. Only in rare cases, the study of the model leads to a brief and accurate answer, which is the ultimate objective of the study. Much more often, studying the model only adds new information related to the problem being studied. As a result, a different approach may be required for FRT, a new vision of the objects of accounting, economic processes or phenomena in order to "grab" the required result from the variety of information. Therefore, the purposefulness of building models is important: not everything that is related with the problem of classification and systematization of phenomena, concepts and objects in the accounting should be studied, but the objective should be achieved as economically as possible: the accuracy in representation of the enterprise as an object of management.

The more basic ideas about the acceptable properties of the investigated object, phenomenon or process are taken into account in construction of the model, the more successful the study of the model is. The financial reporting taxonomy can be considered as logical and mathematical (formal) models, which are the representation of imaginary models through the system of mathematical relations (equations and inequalities, logical expressions, tables, matrices, schemes, etc.). If by the nature of representing the causal relationships the model should be determined to be either deterministic or probabilistic, the taxonomy is appropriate to be classified as the first. Therefore, the financial reporting taxonomy as mathematical modeling of management objects requires a clear action plan, which can be divided into three steps: mathematical model - calculation algorithm - computer program.

In the first step of taxonomy constructing, an "equivalent" of the object of management (enterprise) is chosen which in mathematical form reflects the most important (key) properties of it - the laws and regularities to which it is subject, the structural and information links of the constituent parts of the object of management and etc. The second step is developing or choosing an algorithm for computer-aided implementing a mathematical model. FRT is developed to give it a form that is convenient for the application of approximate numerical methods, the sequence of accounting procedures and logical operations are determined that must be performed to obtain the 
desired results with certain accuracy. The algorithms should not distort the basic properties of the FRT model - the object of management, be economical and adaptive to the peculiarities of the information interests of different users of financial reporting. The third step includes creation of a software for implementation of the algorithm for solving problems using algorithmic languages of programming systems or languages of specific application software packages.

Using FRT as a triad "mathematical model - algorithm of calculation - computer program", the user of financial reporting receives a universal, flexible and relatively accessible tool for assessing the financial standing of the enterprise followed by making economic decisions. Such triad can be tested in "trial computer experiments" to conduct subsequent various and detailed studies for obtaining new information about qualitative and quantitative properties and characteristics of the enterprise as the object of management.

Introducing accurate knowledge into the economic science from qualitative analysis of nonlinear and stochastic models to modern programming languages, provided different methods, techniques and approaches are used, allows to limit intuitive making managerial decisions and extend the limits of application of rational methods.

\subsection{Basic Phases of Mathematical Design of Taxonomy}

Mathematical modeling of taxonomy, for economic systems is the process of constructing, studying and applying models with the following main phases:

- $\quad 1$ st phase. Some knowledge about the original object is supposed to be present. The cognitive capabilities of the model are conditioned by the representation of the essential features (properties) of the original object. Some properties of a modeled object are studied due to neglecting others. For example, if the FRT is based on the prioritization of a reliable determination of the financial result, the users are guided by the principle of prudence (conservatism) and have to ignore to certain extent the principle of historic prime cost. In the case of priority of a reliable assessment of assets, FRT, on the contrary, is focused on the principle of historical prime cost and the principle of accrual. So, FRT, as any model corresponds to the original (enterprise) only in a strictly limited sense. Therefore, in order to study separately the financial standing and the financial results, a few "specialized" FRT models can be constructed that only reflect certain aspects of the investigated object or characterize the object at different levels of detail;

- 2nd phase. In this phase, the FRT appears as an independent object of the study. One of the forms of such study is conducting "model" experiments, when the conditions of the model operation and systematizing the results of experiments are changed on purpose, resulting extensive knowledge about the original company;

- $\quad 3 r d$ phase. The knowledge is transferred from the model to the original, that is, a set of managerial decisions is made, from which the most qualitative ones should be chosen. Managerial decisions are generated following certain rules;

- 4th phase. Practical validation of the obtained FRT model of knowledge (implementation of the results of management decisions) and their use for building (updating) the accounting policy of the enterprise.

We would like to note that the FRT modeling is a cyclic process, that is, the first four-stage cycle can be followed by the second, third one, and so on. Then the knowledge about the object or phenomenon being studied is expanded, deepened and refined, and the original model is gradually improving.
The techniques and rules of clear formulation and ordering of the informational (learning) goals of Bloom's taxonomy can be used [15] to construct FRT which are divided into two domains:

- methods and rules of the first, cognitive domain, involve perception and reproduction of information, as well as solving problems in which the existing knowledge should be reinterpreted, their new associations, structures should be build, and new knowledge should be created. The objectives of this domain are mainly presented in formalized financial statements;

- methods and rules of the second domain (affective) set the objective of formation of emotional and personal attitude to processes and phenomena; they are expressed through the perception of users of reporting, interest, formation of attitude, understanding and making managerial decisions. Such objectives are achieved through disclosure in the notes to the financial statements.

FRT is based on the use of a clear and ordered system of objectives in filing the accounting information, which is very important for building the process of making managerial decisions. First, understanding the objectives of the enterprise, the person who prepares the reporting can organize it, define the primary, basic elements, the order and the prospect of further work; second, knowing the specific objectives users can provide guidance to decision-makers; third, clear formulation of objectives expressed through the results of activities can be reliably and objectively evaluated.

\section{Conclusions}

The financial reporting taxonomy should be understood as the classifications and systematizations of financial reporting elements as an information system and the links between the components of such a system. Understanding the FRT, as well as the circumstances in which such a system can be implemented in the information model of the enterprise for the benefit of effective management and economic decision-making. FRT is aimed at solving managerial problems.

The financial reporting taxonomy belongs to logical and mathematical (formal) models which represent imaginary models through the system of mathematical relations (equations and inequalities, logical expressions, tables, matrices, schemes, etc.) and to deterministic models, by the nature of the representation of causal relationships.

The financial statements taxonomy is based on the use of a clear and ordered system of objectives in filing the accounting information, which is very important for building the process of making managerial decisions. First, understanding the objectives of the enterprise, the person who prepares the reporting can organize it, define the primary, basic elements, the order and the prospect of further work; second, knowing the specific objectives users can provide guidance to decision-makers; third, clear formulation of objectives expressed through the results of activities can be reliably and objectively evaluated.

However, if we analyze the problems of modeling economic systems, when the "human factor" has to be taken into account (weakly structured objects), then the above requirements should be supplemented with the requirements for a precise separation of mathematical and everyday terms, the prudent use of mathematical apparatus to study phenomena and processes, based on the priority of the way "from task to method, and not vice versa", etc.

Introducing accurate knowledge into the economic science from qualitative analysis of nonlinear and stochastic models to modern programming languages, provided different methods, techniques and approaches are used, allows to limit intuitive making managerial decisions and extend the limits of application of rational methods.

Summarizing the above, we would like to highlight the factors that allow combining the elements of accounting in the financial 
statements taxonomy, such as a unified system of classification of sources of information, a unified system of financial reporting indices; methods of information quality control; regulation of information carriers; subordination of information flow and processing methods for management purposes; using feedback in the document flow and more. We would like to note that although many provisions regarding the determining role of the functional accounting subsystem in the enterprise information model have been verified in practice and do not raise doubts, the proposed concept of implementation of FRT should be considered to be a developing one.

\section{References}

[1] Dyrektyva 2013/34/JeS Jevropejsjkogho Parlamentu ta Rady , neoficijnyj pereklad audytorsjkoji palaty Ukrajiny (2013) [Online]. Available: http://www.apu.com.ua/event/771-direktiva-2013-34esevropejskogo-parlament-ta-radi-vid-26-kvitnya-2014reneofitsijnij-perelapad.

[2] Plan implementaciji Dyrektyvy 2013/34/JeS Jevropejsjkogho Parlamentu ta Rady JeS pro richnu finansovu zvitnistj, konsolidovanu finansovu zvitnistj ta pov'jazanu zvitnistj pevnykh typiv pidpryjemstv, [Online]. Available: https://www.kmu.gov.ua/ua / news / 248081506

[3] Pro vnesennja zmin do Zakonu Ukrajiny "Pro bukhghaltersjkyj oblik i finansovu zvitnistj v Ukrajini" vidnosno udoskonalennja dejakykh polozhenj No. 2164-VI (2017) [Online]. Available: https://minfin.com.ua/2017 10/05/30298069/

[4] Introduction to the New EU Accounting Directive http://www.fee.be

[5] Žárová Marcela, «Changes in EU Directives and Impact on Presentation of Financial Statements in the Czech Republic» [Online]. Available: http://www.vse.cz/efaj/99

[6] Zhuk V, «Do problemy oblikovogho zabezpechennja upravlinnja aghrarnym sektorom ekonomiky", Podilsky State Agricultural and Technical University, Vol. 3 (2008) - pp. 478-482.

[7] Voskoboynikov A, "!Sistemnye issledovaniya: bazovye ponyatiya, printsipy i metodologiya», Informational humanitarian portal "Knowledge. Understanding. Skill". No.8, (2013) [Online]. Available: www.rae.ru/snt/?section=content\&op.

[8] Taksonomiya kak istochnik idealnykh form otchetnosti po MSFO [Online] Available: http://www.ifrs.org/XBRL/Resources/Pages/IFRS TaxonomyIllustrated -2015.aspx?

[9] Yefimenko T, «Oblikove zabezpechennja informacijnogho modeljuvannja pidpryjemstva», Bulletin of Kharkiv National Agrarian University, No. 3 (2014) pp. 133-140.

[10] Chto takoe taksonomii v WordPress [Online]. Available: https://wp-kama.ru/id_8218/taksonomii-vwordpress.htm

[11] Gavrilov M., Bredihena M, «Informatsionnoe modelirovanie - osnova dlya sozdaniya edinogo informatsionnogo prostranstva predpriyatiya », Informational and analytical journal, No. 5-6, (2013) [Online]. Available: http://www.remmag.ru/admin/upload_data/remmag/135/NEOLANT.pdf

[12] Polozhennja (standart) bukhghaltersjkogho obliku 16 «Vytraty» [Online]. Available: http://zakon1.rada.gov.ua/laws/show/z0027-00.

[13] Marius Deac, «The new EU accounting Directive - a comparation of reporting requirements» Annals of the «Constantin Brâncuși» University of Târgu Jiu, Economy Series, No 2, (2014) pp.197205.

[14] EFAA Position Paper The Revision of the Accounting Directives Missed Opportunity, May, (2013) [Online]. Available: http://www.efaa.com/files/pdf/Publications

[15] Bloom B, «Taxonomy of educational objectives: The classification of educational goals», New York: Longman, (1984), 207 pages. 